\title{
BASURA Y TESOROS EN EL RELLENO SANITARIO DE RIO AZUL: UNA NUEVA MIRADA A LA "SUIZA DE AMERICA CENTRAL"
}

\author{
Ruth Budd \\ Longwood College, EE. UU.
}

Cuando se piensa en Costa Rica, inmediatamente llegan a la mente visiones de bosques tropicales, extensas playas prístinas y ciudadanos sonrientes y tranquilos. La imagen de Costa Rica es la de un oasis en medio de una Centro América siempre turbulenta, la de un país que todavía ofrece una amable bienvenida a los visitantes.

En su primera novela, Unica mirando al mar ${ }^{1}$, su autor revela otro lado de las imágenes utópicas elaboradas en los folletos turísticos que promocionan al país. Retrata a la cultura costarricense en creciente riesgo de caer bajo la denominación de "cultura desechable": la nación entera corre el peligro de convertirse en un enorme basurero.

En la contemplación de esta sociedad desechable, aun los seres humanos son fríamente "botados" cuando son percibidos como inútiles. Este trabajo pretende demostrar cómo la ubicación del relato en análisis —el relleno sanitario donde la basura de San José metropolitano encuentra su destino final- provee una escena especialmente apropiada para esta perceptiva novela posmoderna de lo carnavalesco y de lo paródico, cuyos protagonistas ya no son personalidades

1. Fernando Contreras Castro, Unica mirando al mar (San José: Farben, 1994). 
relevantes, ricas y famosas, sino "buzos," es decir, exploradores de las profundidades de acuerdo con la aceptación costarricense; honduras que of recen a los personajes una forma de ganarse la vida, escarbando entre la basura botada por sus compatriotas y un medio para tratar de encontrar su propia identidad y el sentido de su existencia.

Dirigidos por Unica Oconitrillo, profesora "botada," y el guachimán despedido Momboñombo Moñagallo, quien fue rescatado por Unica de un intento de suicidio, los buzos empiezan cada día en su reciclado hogar en la periferia del basurero, de igual manera que lo hacen sus contrapartes en el mundo exterior, preparándose para el trabajo, pero con un horario basado en la llegada y salida de los camiones. La productividad alcanzada por cada uno se mide por los "tesoros" que se encuentran en su constante rebuscar entre lasochocientas toneladas de basura echadas diariamente al basurero de Río Azul.

En este oloroso microcosmos donde interactúan todo tipo de personalidades, se somete la vida pasada de cada buzo al "identicidio": nuevas identidades y expectativas reponen las esperanzas y aspiraciones previamente concebidas por cada uno. Algo tan simple como un vestido clerical convierte a un reticente viejo originalmente no pretencioso, en el religioso autoproclamado de la comunidad. De manera similar, una revista desintegrada o una página rota del periódico provoca un éxtasis al Bacán, atrasado hombre-niño adoptado por Unica. Este personaje devora obsesivamente toda palabra escrita, desde tomos de valor intelectual y revistas pornográficas, hasta manuales de instrucción; así llega a ser un experto de la palabra. Su habilidad como lector contrasta vívidamente con el atrasado comportamiento que manifiesta en todas las otras situaciones que vive.

Aun Momboñombo, originalmente un individuo solitario y meditabundo, excepto por un desafortunado incidente activista, inventa un nuevo nombre para sí mismo (nunca se revela su verdadero nombre) y, después de pasar por un breve período de choque cultural, desarrolla una nueva personalidad que se adecúa más a su nueva vida de buzo; organiza entonces a los demás y hace un peregrinaje a la casa 
presidencial para exigir iguales derechos para los buzos, amenazados por el inminente cierre del botadero de Río Azul, su único sustento, y por los planes de prohibirles trabajar y vivir en un nuevo basurero. Es por medio de los esfuerzos de Momboñombo para denunciar la problemática de estas sencillas personas, como Contreras parodia las actitudes materialistas que él siente prevalentes tanto en Costa Rica como en cualquier otra sociedad moderna. Es evidente otra vez que los folletos turísticos, con sus retratos de una sociedad jovial, tolerante y amable a todos, independientemente de su clase social o económica, no son completamente precisos. Tampoco dice la historia total la publicidad regalada a esta "Suiza de América Central," como nación totalmente dedicada a la conservación de los recursos naturales. En su excelente resumen de la literatura costarricense, Rojas y Ovares afirman:

El mundo armónico y familiar propio del estereotipo costarricense, la representación del espacio nacional como un lugar íntimo y conocido, sin conflictos, aparecen profundamente cuestionados en Unica mirando al mar ${ }^{2}$.

A través de toda la novela, Contreras se refiere a la actitud apática y casual de sus conciudadanos, compañeros en asuntos de conservación y reciclaje. Pero aún es más importante su tendencia a condenar a los seres humanos a la misma categoría que a los desechos materiales: "Su propensión a desvalorar a un individuo puede ser interpretada más como resultado de hábitos que de la malicia deliberada, pero sin embargo eso es evidente" (11).

La tradición ha enseñado a los ticos que viven fuera del basurero que las personas que se visten con harapos, que huelen mal y que subsisten de los desechos de los otros, son por su naturaleza, seres inferiores, no inteligentes y que no contribuyen en nada a la sociedad.

2. Margarita Rojas y Flora Ovares, Cien años de literatura costarricense (San José: Farben, 1995) 244. 
La tradición provoca que la sociedad como entidad esquive a ambos: los buzos y su hogar. Culpa además a los mismos buzos de su propia condición, aunque muchos fuesen sacados de la sociedad principal y puestos dentro de una existencia marginalizada. Por ejemplo, Contreras dice a sus lectores que Unica fue despedida de su posición docente cuando le quedaban muchos buenos años para dar a su profesión: «Unica Oconitrillo, maestra agregada, pensionada a la fuerza a sus cuarenta y pico de años, por esa costumbre que tiene la gente de botar lo que aún podría servir largo tiempo» (14).

A pesar de sus esfuerzos por encontrar otro empleo, Unica es eventualmente forzada a usar el basurero como manera de ganar un miserable sustento. Al principio piensa que su situación es sólo temporal, pero al finse da cuenta que no tiene otra alternativa que vivir de los desechos de la otra gente. Momboñombo también fue quitado de su empleo pero en circunstancias diferentes. Como vigilante de una gran biblioteca, descubrió los planes de la administración para vender los libros viejos y no deseados a una compañía privada que los convertiría en papel higiénico. El pensamiento de tal sacrilegio fue más fuerte de lo que un ávido lector podría soportar, así que protestó contra el plan, amenazando con informar a la prensa . Consecuentemente, perdió su empleo y como no tenía otras destrezas, no pudo conseguir otro trabajo, por lo que concluyó que su vida era un fracaso. En una última e irónica tentativa de ganarse la vida, solicitó una posición en la sección literaria del Ministerio de Cultura. Después de todo, razonó, él había leído más libros en su tiempo de vigilante bibliotecario que los que lee la mayoría de la gente en toda su vida. Sin embargo, la reacción del personal del Ministerio de Cultura fue demasiado predecible. ¡La idea de que un mero vigilante pretendía buscar un empleo que requería de un intelectual, era absolutamente ridícula! Momboñombo concluyó que él no era más que una pieza de basura indeseable; por eso decidió "botarse" él mismo en el relleno sanitario, donde esperaba ser aplanado por uno de los camiones. Claro que no había contado con Unica, quien lo salvó de la muerte y quien lucgo le enseñó a reciclar su vida en algo más significativo. 
Aunque la sociedad costarricense puede considerar a los buzos como algo menos que seres humanos, en muchos casos éstos sienten la fuerza de las tradiciones y expectativas sociales. Unica, en un ambiente de pobreza y asco, colecciona todas las botellas de perfume que encuentra, las vierte en una botella grande y generosamente se aplica esta fétida mezcla cada mañana, antes de salir a trabajar. Siempre aconseja a los demás que se cepillen los dientes antes de salir del relleno, como si este único rito pudiera hacerlos más aceptables socialmente. En el techo de su tugurio hay una inservible antena de televisión. Aunque esa antena no funciona ni Unica tiene un televisor, a ella le gusta ver este símbolo de prestigio social en su casita. También goza de servir en una función matriarcal dentro del basurero, arreglando eventos sociales para los buzos, cuidándolos si están enfermos, escuchándolos si están descontrolados. Este papel matriarcal y su insistencia en practicar ciertos ritos del mundo externo, son necesarios porque permiten que ella mantenga un sentido de real normalidad y que se sienta útil y no obsoleta y sin valor.

A diferencia de Unica, quien intenta retener las señales exteriores de status, Momboñombo siente la necesidad de eliminar el bagaje emocional de su vida pasada. Esa eliminación sirve a Momboñombo para liberarse de los sentimientos de amargura, confusión y desesperación que trajo consigo al relleno y lo prepara para adaptarse mejor al desinhibido entorno público del basurero. Su adaptación es tan exitosa que en las pocas ocasiones cuando le es necesario volver al mundo exterior, se percibe completamente aislado en ese mundo. Entonces siente un fuerte anhelo por regresar a su nuevo hogar e interactuar con las únicas personas que lo respetan por lo que es, no obstante su status económico o la ropa que él usa.

En un verboso discurso sobre las causas del asco, Momboñombo analiza cómo las percepciones de una misma persona o cosa, pueden ser completamente opuestas a las de otro individuo: "Así como hay pueblos que saborean algo como un manjar, hay otros que vomitan por lo mismo, y ahí vamos de asco en asco, cada uno se retrata en su manera 
de mostrar la repugnancia" (29). Estas consideraciones le ayudan a Momboñombo a aliviar el efecto de las reacciones negativas de la gente ajena al relleno; atenúa un poco el dolor que siente al ser rechazado por las personas que lo ven como un vagabundo sucio y malo.

Las vívidas imágenes y metáforas de esta novela cumplen un papel crítico. La playa y el agua enfatizan el aspecto grotesco del relleno, se describe el "mar" de basura, las olas, los pájaros volando sobre la "ciudad flotante," los peces de aluminio, el aroma distintivo del área y la costa desde la cual los buzos salen para empezar su trabajo cotidiano. Aun la nominación del relleno sanitario, un nombre que usualmente evoca escenas pintorescas y tranquilas, es en este caso una parodia irónica. Río Azul es todo menos un río hermoso.

Además de su abundante uso de la parodia, Unica mirando al mar es un relato que provee un buen ejemplo del aspecto borroso de los límites posmodernos entre las clases alta y baja, o mejor dicho, entre la "crema" y la "basura". Los buzos, considerados socialmente inferiores en Costa Rica, son presentados como los que muestran las más genuinas emociones y la mayor preocupación por sus semejantes. Ellos forman una comunidad íntima y solidaria, todos se cuidan y ayudan a cualquier compañero en problemas. Rojas y Ovares comentan sobre esta presentación de los valores positivos como opuesta a la actitud despectiva de los miembros de la clase alta: «Los valores positivos, como la solidaridad humana, el amor, el cariño, la alegría, están dentro del basurero» ${ }^{3}$.

Las alegrías y las tragedias de los buzos, no disminuidas por la moderación y buen gusto de la sociedad "normal," son mostradas en li desvergonzada exhuberancia de la boda de Unica y Momboñombo, ('on cl autodenominado Oso Carmuco oficiando, y más tarde por su Irislc conmiseración por la muerte del Bacán, hecho que provoca el s'verualislamiento emocional de Unica. Sus emociones y sus reaccioul's producen un fucrte contraste con las de la élite costarricense,

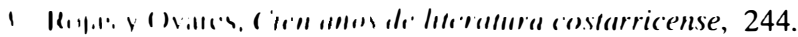


desinteresada por la ecología y por la humanidad; también se evidencia una discrepancia con el gobierno del país, por su desinterés hacia las peticiones de los buzos. Momboñombo recuerda tristemente que conocía a don Pepe Figueres, el expresidente "abuelito" de Costa Rica, quien tenía la reputación de ser "presidente de la gente" dispuesto siempre a escuchar a cualquiera, aun a los considerados insignificantes. Momboñombo no entiende por qué el Presidente del momento, hijo de Don Pepe, no responde igualmente a la carta meticulosamente escrita y llevada a la Casa Presidencial. ¿No era cierto que un guarda de la oficina presidencial prometió que el presidente recibiría la carta? Además, ¿no tiene Costa Rica fama mundial por el respeto que se da en el país a todas las personas, incluyendo a las de las clases más bajas?

Al no oír ninguna respuesta, Momboñombo organiza a los habitantes del relleno y realiza una marcha pacífica por las calles de San José hasta la Casa Presidencial. Al principio, la policía nerviosa y sorprendida no sabe cómo reaccionar ante este harapiento grupo protestante. Luego resuelven el problema atacando con mangueras para dispersarlo. Esta escena es un perfecto ejemplo de lo carnavalesco:

Los buzos sólo gritaban y brincaban empapados de pies a cabeza; tan, tan mojados ya que hasta se les estaba destiñendo el color grisáceo mugre de sus caras y sus brazos. La ropa se les estaba cayendo en tiras y cuando la manguera apuntaba más directamente, más de uno caía sentado en el pavimento, muerto de la risa y con algún pedazo menos de su indumentaria (140).

Pero a pesar del ambiente burlesco, el episodio termina en tragedia con la repentina neumonía y la subsecuente muerte del Bacán, porque ningún médico quiso ir al relleno a atenderlo. Nadie, ni aun los "humanitarios" dedicados a salvar vidas, valora la "basura humana" de Río Azul. Estas actitudes y aversiones son causadas por costumbres previas, por conductas adquiridas y por el asco al que se refirió Momboñombo anteriormente. 
Contreras parodia el papel de los Estados Unidos como líder de cliciencia, describiendo las tentativas del gobierno costarricense por convencer a sus ciudadanos acerca de los beneficios que logrará el barrio donde se ubique el nuevo relleno sanitario: «el gobierno prometía en su lugar un relleno sanitario a la altura de los rellenos modelo de Estados Unidos, ésos donde hasta las ratas comen con tenedor y cuchillo» (50). Esta promesa es dada como respuesta a las muchas protestas de barrios e individuos, que no quieren los olores y cl panorama de otro Río Azul en sus propios patios. Cuando fracasa la propaganda gubernamental, se hace necesario tomar medidas más fuertes, ya que obviamente tiene que haber un basurero en algún lugar. La búsqueda de ese sitio adquiere un aspecto también carnavalesco, cuando los ticos montan un tipo de competencia al revés para asegurarse que sus respectivos barrios NO serán ganadores del gran premio. Los buzos rioazulanos quedan por supuesto atrapados entre los planes para cerrar el viejo relleno y la gente que vive en los barrios vecinos al relleno de Río Azul, se encuentra agotada por años de sufrimiento ante la vista y el olor de los desechos materiales y también por la "basura humana". Sus quejas son las que activan los planes de prohibición del futuro buceo, sin importar las desastrosas consecuencias que esta medida pueda traer a los individuos acostumbrados por mucho tiempo a subsistir de las cosas botadas por otros.

A través de las palabras de Momboñombo, Contreras culpa a la misma sociedad del fenómeno del buceo, explicando: «mucha gente aquí no sabe ni leer ni escribir ni hacer otra cosa que rebuscarse una platilla con lo que se encuentran en el basurero» (120). El exvigilantebibliotecario apela al Presidente de la República declarando que «no está bien que hayamos personas que tengamos que vivir entre la basura pero tampoco es el caso de que a todos nosotros nos dejen morirnos de hambre ahora que la basura va a estar en manos de la empresa privada» (120). Irónicamente Momboñombo comenta en su carta al presidente que «aunque estemos tan cerca de la Casa Presidencial yo sé que hay cosas que no se ven si uno no afina el ojo y cosas que no se huelen si 
uno no afina la nariz» (122). Esas frases enfatizan la apática práctica tica, de no hacer caso a lo que creen que no los impacta directamente como individuos. Así como muchas personas saben que no necesitan escarbar en el basurero, tampoco niegan que la práctica del buceo no se debe permitir.

El Bacán, abandonado por todos menos por su "rellenaria" familia inmediata, es un símbolo de los agonizantes buzos. Desde el momento de la muerte de este personaje hasta el final de la novela, Unica nunca habla más, cae en un tipo de limbo, abandonando totalmente sus esfuerzos previos por lograr, tanto como sea posible, que el relleno parezca una casa normal; ahora ella no presta atención a nadie ni a nada. Momboñombo, en estado de pánico, decide llevarla tan lejos de la vida sórdida del basurero como pueda; con sólo unas pocas cosas tomadas del tugurio y después de un breve viaje, llegan a Puntarenas, puerto decadente de la costa del Pacífico.

El destino de los buzos así como el estado mental de Unica depende de la imaginación de los lectores; es posible entonces afirmar que los buzos seguirán siendo marginados, rechazados y estigmatizados. Tampoco es difícil predecir el aumento de los problemas ecológicos en Costa Rica porque cada vez más y más ticos, influidos por las prácticas de sus contrapartes "gringos," siguen agrediendo la naturaleza. Incluso Momboñombo lamenta que toda Costa Rica se haya convertido en un gigantesco receptáculo de basura y que todos los ticos sean hasta cierto punto, buzos:

porque todos, absolutamente todos, nos vemos obligados a bucear en las profundidades del humo de los escapes en busca de un poco de aire para respirar; todos, absolutamente todos, nos vemos obligados a bucear en las profundidades de las aguas contaminadas en busca de beber; todos, absolutamente todos, nos vemos obligados a bucear entre los alimentos contaminados de agroquímicos y plaguicidas en busca de algo fresco de comer; todos, absolutamente todos, nos vemos obligados a bucear entre 
la basura que hablan los políticos en busca de una actitud sincera que reflexione auténticamente en lo que nos estamos convirtiendo vertiginosamente (116).

Rojas y Ovares creen que uno de los aspectos más importantes de Unica mirando al mar es la aparente convicción del autor en el poder de la comunicación literaria:

Sobre todo, revela un grado mayor de confianza en la posibilidad comunicativa de la literatura, como un acto de transmisión de un saber y como denuncia de una situación indebida. Esto queda patente en los fragmentos de carácter más bien ensayístico que se incluyen al final del texto ${ }^{4}$.

Con el uso de la parodia y de un grupo muy marginado de la sociedad costarricense, Contreras implica que lo que se necesita en Costa Rica - y realmente en cualquier sociedad moderna- es un esfuerzo masivo de reciclar, un esfuerzo mediante el cual no solamente los objetos materiales deben recibir más respeto y valor, sino donde las actitudes dañinas y los prejuicios del pasado, deben ser reexaminados también.

4. Rojas y Ovares, Cien años de literatura costarricense, 244. 